UDC 635.261-295.4

COBISS.SR-ID: 219340556

Original research paper

Acta Agriculturae Serbica, Vol. XX, 39 (2015); 41-49

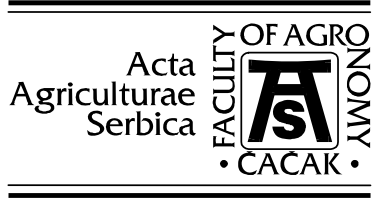

\title{
Influence of tank mixtures of pre-emergence herbicides on growing leeks (Allium porrum L.)
}

\author{
Nina Gerasimova ${ }^{1}$ and Milena Yordanova ${ }^{2}$ \\ 1 Bulgarian Food Safety Agency, 17, Hristo Botev blvd., Sofia, Bulgaria \\ 2 University of Forestry, Faculty of Agriculture, 10, Kliment Ochridski blvd., \\ 1756, Sofia, Bulgaria
}

\begin{abstract}
The effect of mixtures of pre-emergence herbicides on weed infestation and yield of leek was evaluated. Three tank mixtures were applied: s-metolachlor (Dual Gold $960 \mathrm{EC}$ at a dose of $80 \mathrm{ml} / \mathrm{da})+$ oxyfluorfen (Goal $2 \mathrm{E}$ at a dose of $100 \mathrm{ml} / \mathrm{da}$ ); smetolachlor (Dual Gold $960 \mathrm{EC}$ at a dose of $60 \mathrm{ml} / \mathrm{da}$ ) + oxyfluorfen (Goal $2 \mathrm{E}$ at a dose of $75 \mathrm{ml} / \mathrm{da}$ ); and s-metolachlor (Dual Gold $960 \mathrm{EC}$ at a dose of $40 \mathrm{ml} / \mathrm{da}$ ) + oxyfluorfen (Goal $2 \mathrm{E}$ at a dose of $50 \mathrm{ml} / \mathrm{da}$ ). The number of weeds was recorded following the application of the tank mixture. It was found that treatment with a tank mixture of herbicides Dual Gold 960 EC and Goal 2 E caused a reduction in weed infestation at all three application rates as compared to the control. The lowest weed infestation was established after treatment with the highest doses of herbicides. It was suggested that the applied herbicide mixture could be used effectively at the leeks growth stage.
\end{abstract}

Key words: Allium porrum, metolachlor, oxyfluorfen, weeds, yield.

Received: 7 April 2015 / Accepted: 18 September 2015 
Acta Agriculturae Serbica, Vol. XX, 39 (2015); 41 - 49

\section{Introduction}

Leeks (Allium porrum L.) are members of the onion family, closely related to onion, garlic, shallots and chives. Leeks are grown everywhere, and they develop long succulent white stems which are used as an onion substitute in many dishes. The best place for growing leeks is in full sun; under shaded conditions, plants remain smaller with thinner stems and lower yield (Cholakov 2009).

Weeds are competitors of most vegetable crops and can reduce their yields significantly. The main annual weeds that occur on arable land under cultivation of species of the family Alliaceae are different types of amaranth, fat-hen, thornapple, pale persicaria, bristle-grass, cockspur, red finger-grass etc. Also, infestation of arable land with perennial weeds such as Johnson grass, creeping thistle and field bindweed has been observed (Tonev 2000). A significant decrease in the occurrence of annual dicotyledonous weed plants was established after prometrin or linuron spraying before planting the leek seedlings (Fetvadzhieva et al. 1991). The expansion of monocotyledonous and some dicotyledonous weeds has significantly slowed down mainly after the use of propachlor, metolachlor or ethofumesate before planting (Tonev 2000).

Two herbicides viz. oxadiazon [5-terbutyl-3-(2.4-dichloro-5isopropoxyphenyl)-1,3,4-oxadiazol-2-one] and oxyfluorfen [2-chloro-1-(3ethoxy-4-nitrophenyl)-4-(trifluoromethyl) benzene] were tested on garlic. They were applied before planting cloves or later at the 3-4 leaf stage. Both herbicides resulted in a reduction of weed infestation but significant yields were obtained only under treatment with oxyfluorfen. Pendimethalin treatment before planting gave varying results (Qasem 1996). In onions, treatment with oxyfluorfen at the 3-4 leaf stage resulted in the best effect against weed infestation and led to high yields (Qasem 2005). Pendimethalin, oxadiazon and oxyfluorfen applied as preemergence herbicides during the planting of onions, or 7 days afterwards, lead to sustainable reduction of weed infestation (75-99\%) (Babiker and Ahmed 1986). In leeks, the highest yield was found after foliar treatment with oxyfluorfen at a dose of $360 \mathrm{~g}$ ai/ha (Karkanis et al. 2012).

Up to date, there has been limited research on weed control during leek growing (Den Hollander et al. 2007; Gilreath et al. 2008; Karkanis et al. 2012). It was reported that metolachlor, oxyfluorfen, prodiamine and pendimethalin have a prolonged effect and the highest efficacy against Eclipta alba (L.) Hassk (Gilreath et al. 2008). Damage to Solanum americanum P. Mill. and Amaranthus viridis L. development was found after treatment with metolachlor, oxyfluorfen, pendimethalin and prodiamine (Gilreath et al. 2008).

In Bulgaria, the only herbicide registered for use in the cultivation of leeks is metazachlor. Information about the influence of herbicides on the development of leeks is insufficient. Therefore, the objective of this research was to study the efficacy of different doses of tank mixture of oxyfluorfen + s-metolachlor against 
Acta Agriculturae Serbica, Vol. XX, 39 (2015); 41 - 49

weed infestation and their influence on length and diameter of the false stem, and yield.

\section{Materials and methods}

The research was conducted in the period 2010-2012 in the experimental field of the University of Forestry - Sofia, on a Fluvisol soil. The leek cultivar 'Bulgarian Giant' was grown through seedlings which were planted in the second half of June according to the scheme $60+25+25+25+25 / 15$. The preceding crop was broccoli. The leek was cultivated by drip irrigation. Each trial was laid out in a randomized block design with four replications $(4 \times 40)$, with protection zones. The experiment included five treatments: I - control - untreated and weeded manually (K); II - control - untreated and non-weeded $\left(\mathrm{K}_{0}\right)$; III - treated with smetolachlor (Dual Gold $960 \mathrm{EC}$ at a dose of $80 \mathrm{ml} / \mathrm{da}$ ) + oxyfluorfen (Goal $2 \mathrm{E}$ at a dose of $100 \mathrm{ml} / \mathrm{da}$ ); IV - treated with s-metolachlor (Dual Gold $960 \mathrm{EC}$ at a dose of $60 \mathrm{ml} / \mathrm{da}$ ) + oxyfluorfen (Goal $2 \mathrm{E}$ at a dose of $75 \mathrm{ml} / \mathrm{da}$ ); V - treated with s-metolachlor (Dual Gold $960 \mathrm{EC}$ at a dose of $40 \mathrm{ml} / \mathrm{da}$ ) + oxyfluorfen (Goal $2 \mathrm{E}$ at a dose of $50 \mathrm{ml} / \mathrm{da}$ ). The number of weeds was recorded 30, 60 and 90 days after treatment (DAT - day after treatment) with the tank mixture at fixed sites of $1 \mathrm{~m}^{2}$, for each treatment and replicate. The efficacy of the tested tank mixtures was recorded by Abbot's formula:

$\mathrm{WG} \%=(\mathrm{CA}-\mathrm{TA} / \mathrm{CA}) \times 100$, where:

$\mathrm{WG} \%$ - the percentage efficacy of the herbicides;

CA - living individuals in the control after treatment;

TA - individuals living in the variant after treatment.

The length and diameter of the false stem were measured on 10 plants, and the average results were presented. The total yield was established in tons per decare $(\mathrm{t} / \mathrm{da})$ in replications and variants. Data were subjected to statistical analysis using dispersion method. Means were separated by Tukey test.

\section{Results and Discussion}

The level of weed infestation in the agrocenosis of leeks recorded 30 and 60 days after treatment is given in Figure 1. In this agrocenosis the following weed species were established: cockspur (Echinochloa crus-galli L.), red finger-grass (Digitaria sanguinalis (L.) Scop.), galinzoga (Galinsoga parviflora Cav.), amaranth (Amaranthus retroflexus L.), purslane (Portulaca oleracea L.), and pale persicaria (Polygonum lapathifolium L.). 
Acta Agriculturae Serbica, Vol. XX, 39 (2015); 41 - 49

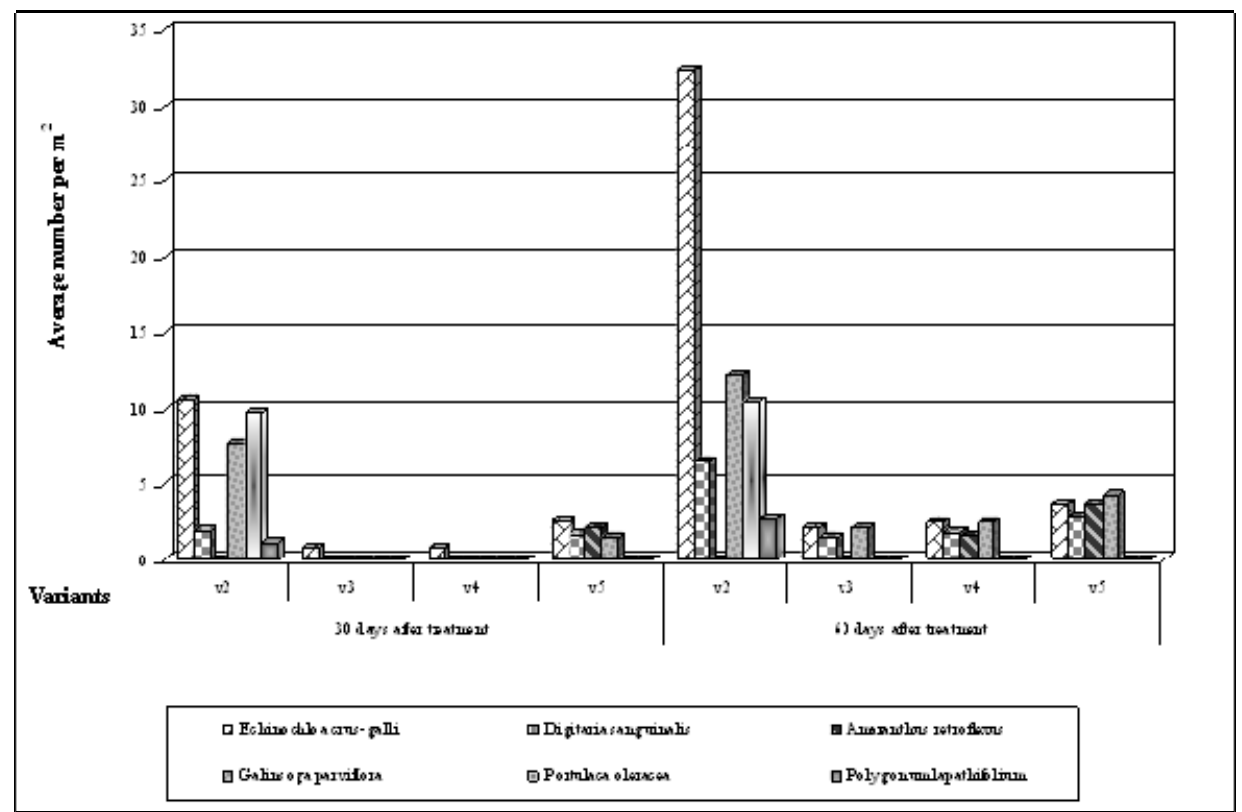

Fig. 1. Average number of weed species $/ 1 \mathrm{~m}^{2}$ after treatment with tank mixtures of pre-emergence herbicides at 30 and 60 DAT

At 30 DAT, the strongest weed infestation was established in Variant II (untreated control) where the most widespread weed plants were cockspur, purslane and galinzoga. Among the variants treated, the highest weed infestation was observed in Variant V (the lowest doses of both herbicides). In all variants, an increase in weed infestation at 60 DAT was established. The lowest level of weed infestation was found in Variant III after application of higher doses of the herbicide mixture, followed by Variant IV.

The efficacy of the applied mixtures of pre-emergence herbicides against weeds is shown in Fig. 2.

The lowest herbicide efficacy against red finger-grass (12.5\%), cockspur (75.2\%), and galinzoga (80.3\%) was established in Variant V (Dual Gold 960 EC at a dose of $40 \mathrm{ml} / \mathrm{da}+$ Goal $2 \mathrm{E}$ at a dose of $50 \mathrm{ml} / \mathrm{da}$ ). The toxicity of the tank mixture to the other weeds in the agrocenoses interfering with leek production was above $90 \%$. In Variant III, herbicides showed an efficacy of $87.5 \%$ against red finger-grass, $100 \%$ against amaranth and pale persicaria. Increased efficacy in all variants was established at 60 DAT since the lowest efficacy was recorded in Variant V-against red finger-grass - 55.7\% and against galinzoga - 65.3\%. In the observed area, a slight increase in the number of weed species in the leek agrocenoses was observed at 90 DAT (Fig. 3). Treatments resulted in a low growth rate of existing weed species as they did not compete with the growth of leek plants. Therefore, it might be concluded that treatment with the highest dose 
Acta Agriculturae Serbica, Vol. XX, 39 (2015); 41 - 49

of herbicides decreased the weed infestation. The higher dose of a.i. Smetolachlor inhibited the development of cockspur in Variant III and enhanced herbicide efficacy to $95.9 \%$; toxicity to red finger-grass was $77.4 \%$. The lower dose of a.i. S-metolachlor (Variant V) revealed a lower effect against cockspur $(89.9 \%)$ and red finger-grass $(51.6 \%)$. A high efficacy against amaranth, purslane and galinzoga was established in Variant III after applying the higher dose of a.i. oxyfluorfen. In Variant V, efficacy against these weeds was $83.5 \%, 89.1 \%$, and $63.5 \%$, respectively. Similar results were reported by other authors (Babiker and Ahmed 1986).

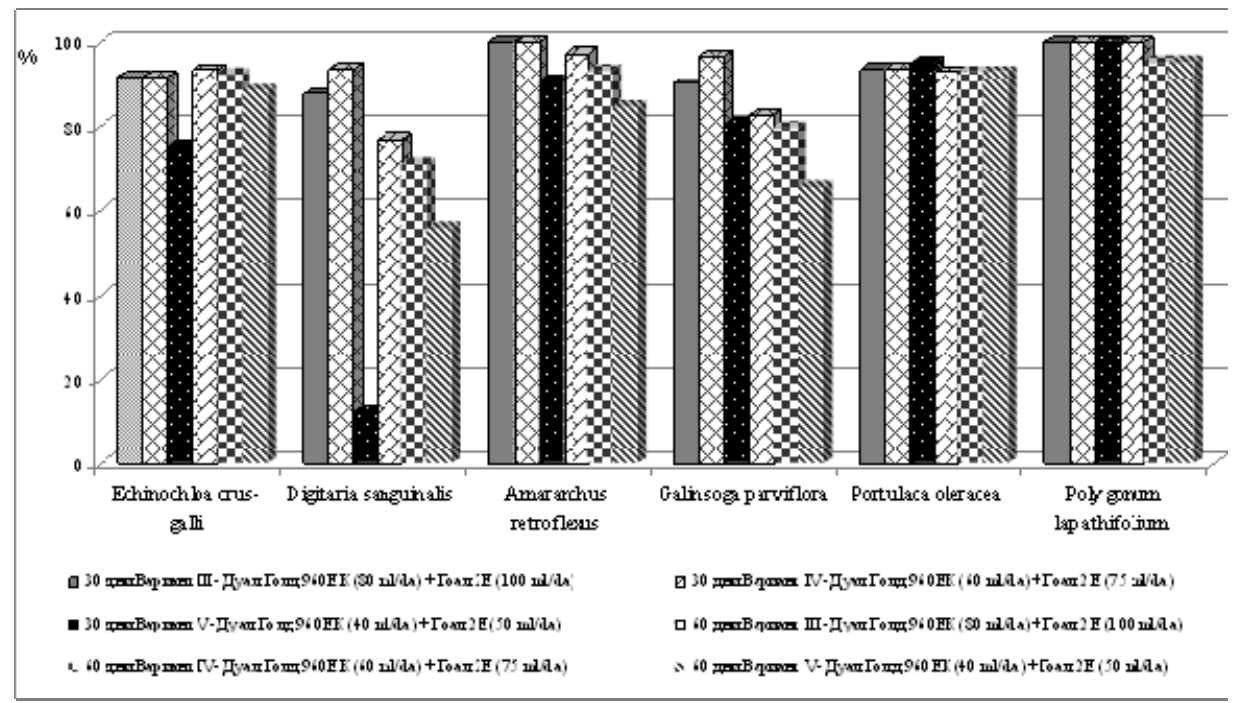

Fig. 2. Efficiency of pre-emergence herbicide tank mixtures compared to the control

The mean values of stem length and diameter in leek are presented in Fig. 4. The thinnest stems were recorded in Variant II (untreated control) as the result of shading by the weed plants. Our results are in good concordance with those demonstrated by Cholakov (2009) and Karkanis et al. (2012). The highest values of the studied traits were recorded in Variant I, followed by Variant III. Based on the results reported here, it can be suggested that a direct correlation between the levels of weed infestation and the length and diameter of the stem exists. 
Acta Agriculturae Serbica, Vol. XX, 39 (2015); 41 - 49

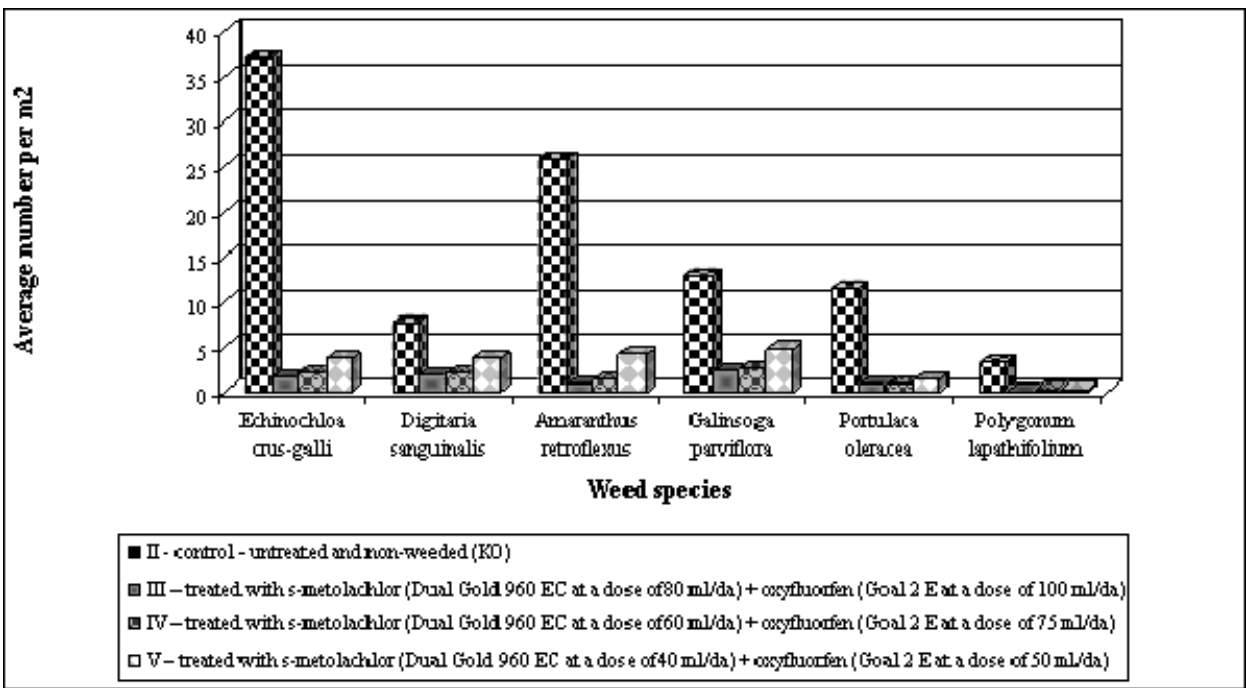

Fig. 3. Average number of weed species/1 $\mathrm{m} 2$ after treatment with tank mixtures of pre-emergence herbicide at 90 DAT

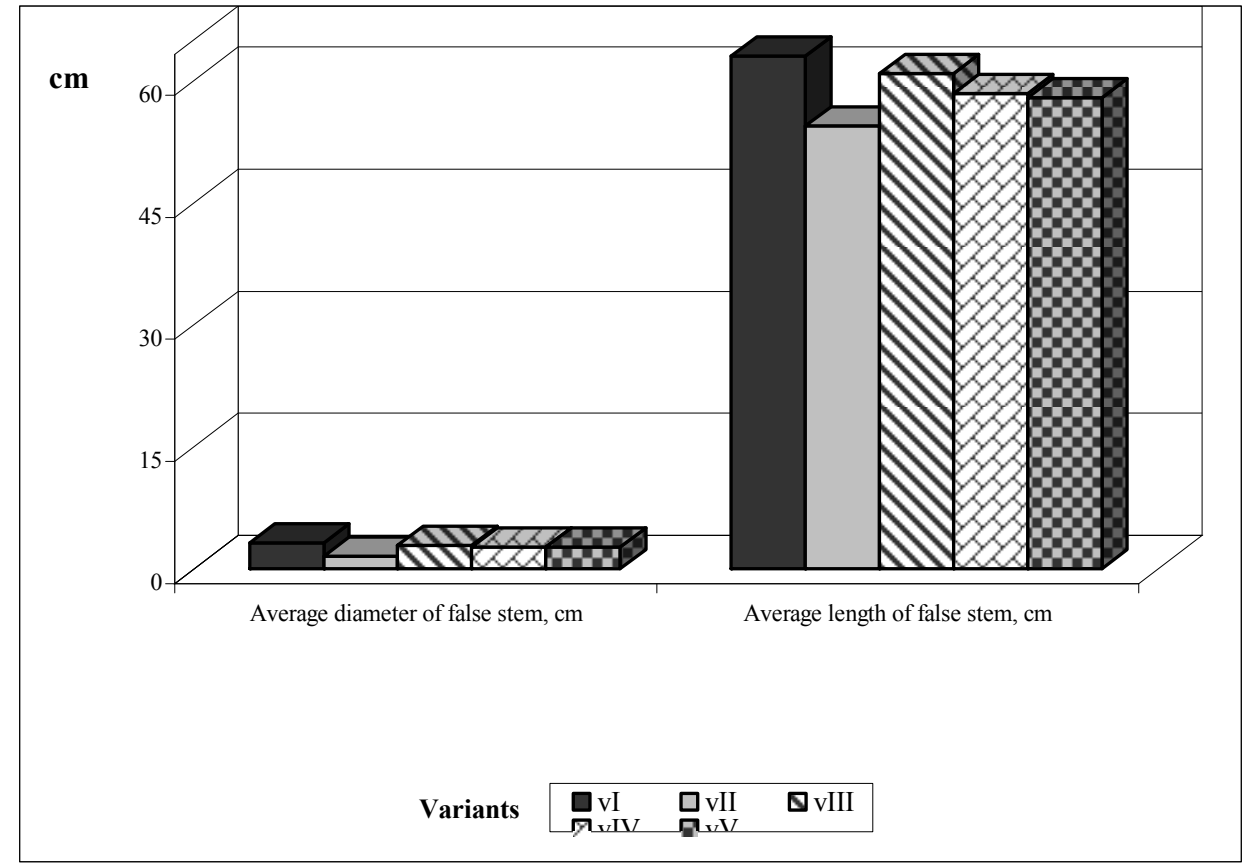

Fig. 4. Average length and diameter of false stem $(\mathrm{cm})$ 
Acta Agriculturae Serbica, Vol. XX, 39 (2015); 41 - 49

Stem length differed from the other tested variants only in Variant II (untreated control) (Table 1).

Table 1. Average value of the studied biometric parameters and the obtained yield (2010-2012)

\begin{tabular}{|c|c|c|c|}
\hline Variants & $\begin{array}{c}\text { Average false } \\
\text { stem length, cm }\end{array}$ & $\begin{array}{c}\text { Average false } \\
\text { stem diameter, cm }\end{array}$ & $\begin{array}{c}\text { Average yield, } \\
\mathrm{t} / \mathrm{da}\end{array}$ \\
\hline 1 & $63^{\mathrm{a}}$ & $3.24^{\mathrm{a}}$ & $7.03^{\mathrm{a}}$ \\
\hline 2 & $54,4^{\mathrm{b}}$ & $1.56^{\mathrm{c}}$ & $1.93^{\mathrm{d}}$ \\
\hline 3 & $60.9^{\mathrm{a}}$ & $2.85^{\mathrm{b}}$ & $5.9^{\mathrm{b}}$ \\
\hline 4 & $58.4^{\mathrm{b}}$ & $2.69^{\mathrm{b}}$ & $5.57^{\mathrm{b}}$ \\
\hline 5 & $57.9^{\mathrm{b}}$ & $2.68^{\mathrm{b}}$ & $5.1^{\mathrm{c}}$ \\
\hline
\end{tabular}

Means with the same letter in each column are not significantly different using Tukey`s test $(\mathrm{P} \leq 0.05)$

Treatments with the herbicide tank mixtures (III-V) showed no difference in this parameter. Both controls (hoed and untreated) had respectively the largest and smallest values of these traits. The results reflected the average yield of leek. The variants treated with tank mixtures of pre-emergence herbicides exceeded the yield obtained under cultivation without chemical or mechanical treatments and were lower than those with manual removal of weeds.

\section{Conclusion}

It has been found that treatment with the tank mixture of pre-emergence herbicides Dual Gold 960 EC and Goal 2 E caused a reduction in weed infestation at the three application rates as compared to the control. The lowest weed infestation was observed in Variant III treated with the highest doses of herbicides (Dual Gold $960 \mathrm{EC}$ at a dose of $80 \mathrm{ml} / \mathrm{da}+$ Goal $2 \mathrm{E}$ at a dose of 100 $\mathrm{ml} / \mathrm{da})$.

There was a high herbicidal efficacy of the studied tank mixture and the length of toxicity for more than three months.

It has been found that after treatment with Dual Gold 960 EC $(80 \mathrm{ml} / \mathrm{da})+$ Goal 2 E $(100 \mathrm{ml} / \mathrm{da})$ the efficacy against observed weed species in the observed area was $82.7 \%$ and $97.1 \%$. This variant is closest to the control values of the indicators viz. length and diameter of the stem and yield of leek.

The applied herbicide tank mixtures can be used easily during the growing stage of leeks and they efficiently control the widespread monocotyledonous and dicotyledonous weed species. 
Acta Agriculturae Serbica, Vol. XX, 39 (2015); 41 - 49

\section{References}

Babiker A. G. T., Ahmed M. K. (1986): Chemical weed control in transplanted onion (Allium cepa L.) in the Sudan Gezira. Weed Res., 2 (26): 133-138.

Cholakov, D. T. (2009): Vegetable growing. Plovdiv. (in Bulgarian)

Den Hollander N. G., Bastiaans L., Kropff M. J. (2007): Clover as a cover crop for weed suppression in an intercropping design: II. Competitive ability of several clover species. Eur. J. Agron., 26 (2): 104-112.

Fetvadzhieva, N., A. Zhelev, Z. Dechkov, P. Pavlov, A. Dimov, V. Spassov, V. Topalov, R. Kondarev. (1991): Herbology, Sofia, Zemizdat. (in Bulgarian).

Gilreath J. P., Santos B. M., Gilreath Ph. L., Maynard D. N. (2008): Efficacy of early post-transplant herbicides in leeks (Allium porrum L.). Crop Protection, 27 (3-5): 847-850.

Karkanis A., Bilalis D., Efthimiadou A., Katsenios N. (2012): Comparison between conventional and organic weed management: growth and yield of leek (Allium porrum L.). Hort. Sci. (Prague) 39 (2): 81-88.

Qasem J. R. (1996): Chemical weed control in garlic (Allium sativum L.) in Jordan. Crop Protection, 15 (1): 21-26.

Qasem J. R. (2005): Chemical control of weeds in onion (Allium cepa L.). J. Hort. Sci. \& Biotech., 80 (6): 721-726.

Tonev, T. (2000): Manual for integrated weed control and crop farming. Plovdiv, Agricultural University - Plovdiv, vol. 2. (in Bulgarian). 
Acta Agriculturae Serbica, Vol. XX, 39 (2015); 41 - 49

\title{
UTICAJ PRIMENE SMEŠE HERBICIDA PRE NICANJA KOD PRAZILUKA
}

\author{
Nina Gerasimova ${ }^{1}$ i Milena Yordanova ${ }^{2}$ \\ 1 Bugarska agencija za sigurnost hrane, 17, Hristo Botev blvd., Sofija, Bugarska \\ 2 Šumarski univerzitet, Poljoprivredni fakultet, 10, Kliment Ohridski blvd., 1756, \\ Sofija, Bugarska
}

\section{Rezime}

Ispitivan je uticaj mešavine herbicida pre nicanja na zakorovljenost i prinos praziluka. Primenjene su tri smeše od: s-metolahlor (Dual Gold 960 EC u količini od $80 \mathrm{ml} / \mathrm{da}$ ) + oksifluorfen (Goal $2 \mathrm{E}$ u količini od $100 \mathrm{ml} / \mathrm{da}$ ); s-metolahlor (Dual Gold 960 EC u količini od $60 \mathrm{ml} / \mathrm{da}$ ) + oksifluorfen (Goal 2 E u količini od $75 \mathrm{ml} / \mathrm{da}$ ); i s-metolahlor (Dual Gold 960 EC u količini od $40 \mathrm{ml} / \mathrm{da}$ ) + oksifluorfen (Goal 2 E u količini od $50 \mathrm{ml} / \mathrm{da}$ ). Određen je broj korova nakon primene herbicida. Utvrđeno je da je primenom Dual Gold 960 EC i Goal 2 E smeše smanjena zakorovljenost $u$ sva tri tretmana $u$ poređenju sa kontrolom. Najmanja zakorovljenost je zabeležena nakon primene herbicida u najvišim dozama. Predloženo je da se herbicidi primenjuju u fazi rasta praziluka.

Ključne reči: Allium porrum, metolahlor, oksifluorfen, korov, prinos. 